\title{
Pendampingan Pembuatan Alat Permainan Edukatif (APE) Pengenalan Literasi Untuk Anak Usia Dini
}

\author{
Durtam $^{1}$, Jazariyah ${ }^{2}$ \\ IAIN Syekh Nurjati Cirebon \\ ${ }^{1}$ e-mail: zisandurtam@gmail.com \\ 2 e-mail: jaza.prudent@gmail.com
}

\begin{abstract}
ABSTRAK
Literasi dasar sebagai kecakapan hidup diantaranya adalah literasi baca tulis dan numerasi. Kemampuan ini perlu untuk dikembangkan sejak anak usia dini. Dalam pelaksanaan pengenalan literasi ini diharapkan guru pendidikan anak usia dini mampu untuk mendesain sesuai dengan kekhasan pembelajaran di Pendidikan Anak Usia Dini (PAUD). Guru dituntut untuk kreatif dalam membuat Alat Permainan Edukatif (APE) sebagai alat bantu untuk mengenalkan literasi. Kegiatan Pengabdian ini dimaksudkan untuk melakukan pendampingan dalam rangka membantu guru untuk meningkatkan kreativitas dalam pembuatan APE untuk pengenalan literasi. Tiga strategi dalam pengabdian di laksanakan, strategi pelaksanaan pengabdian secara teoritik, praktek dan dampingan. Hasil dari kegiatan pendampingan ini salahsatunya muncul modifikasi atau rancangan APE baru berupa kalender hijaiyah yang merupakan ide guru PAUD untuk pengenalan huruf hijaiyah.
\end{abstract}

Kata kunci: APE Literasi, Permainan Literasi, Anak Usia Dini

\begin{abstract}
Literacy fundamentals as life skills of them are read-write literacy and numerical literacy. This capability needs to be developed since early childhood.It is hoped that in the implementation of the introduction of literacy, teachers of early childhood education capable of designing in accordance with the peculiarities of their experiences in the education of their children early childhood education - teachers required to be creative in making education toys as the tools to introduce literacy. Activities devotion is intended to give assistance in the context of assisting teachers in improving creativity in the manufacture of APE for the introduction of literacy. Three strategies in devotion to conducting, the implementation of devotion in theoretical strategy, practice, and assisted by each.The result of this flanking activity is a new design of APE, which was initiated in the form of the calendar hijaiyah to introduce hijaiyah letters to the children.
\end{abstract}

Keywords: Edutoys, Literacy, Early Childhood 


\section{PENDAHULUAN}

Pola pembelajaran pada pendidikan anak usia dini (PAUD) memiliki kekhasan tersendiri yang tidak dapat disamakan dengan jenjang pendidikan lain. Belajar dalam PAUD diperoleh melalui kegiatan bermain. Permainan-permaian yang dilakukan dalam kegiatan anak usia dini dilakukan sebagai upaya untuk stimulasi tumbuh kembang anak. Praktek permainan pada anak usia dini tidak jarang membutuhkan sebuah media atau yang dinamakan alat permainan edukatif (APE).

Pembelajaran melalui bermain dapat memenuhi rasa ingin tahu anak. Dengan melakukan pengamatan dan mendapat banyak latihan dalam sebuah permainan anak akan dapat menemukan pengetahuannya sendiri (Pradana, 2016). Stimulasi yang tepat untuk mengembangkan aspek perkembangan anak usia dini dapat dilakukan dengan kegiatan bermain. Kenyataan ini harus dapat disadari oleh guru sebagai pendidik anak usia dini, sehingga guru tidak akan melakukan kesalahan dalam usaha stimulasi perkembangan anak. Aspek-aspek perkembangan anak usia dini yang harus distimulasi terdiri dari enam aspek, yakni: aspek kognitif, aspek nilai agama dan moral, aspek bahasa, aspek seni, aspek sosial emosional dan aspek fisik motorik. Untuk mengembangkan aspek ini guru harus memiliki kreativitas dalam mendesain permainan serta alat permainan edukatif.

Pada setiap tahapan usia, anak akan memiliki kekhasan pencapaian yang dapat dilihat pada Standar Tingkat Pencapaian Perkembangan Anak (STPPA). Dalam STPPA masing-masing tahapan usia akan memiliki tingkat pencapaian perkembangan yang berbeda beda. Anak usia 2 tahun akan memiliki tahapan perkembangan bahasa yang berbeda dengan anak usia 5 tahun.

Perbedaan pencapaian tiap tahapan dan adanya standar pencapaian perkembangan untuk tiap usia ini sering kali diabaikan oleh orangtua. Faktanya di lapangan orangtua yang mengirimkan anak usia dini dalam PAUD menghendaki anak-anak memiliki kesiapan untuk memasuki jenjang pendidikan selanjutnya yakni Sekolah Dasar. Pemenuhan tuntutan tersebut memaksa beberapa lembaga PAUD justru lebih menekankan pengembangan kognitif dan bahasa anak dengan berbagai kegiatan yang sering kali justru melanggar sifat alamiah dasar anak yakni bermain. Anak usia dini dibebani baca tulis hitung (CALISTUNG).

Kemampuan membaca menulis dan berhitung pada anak usia dini sesungguhnya erat kaitannya dengan pengenalan literasi. Aspek yang ingin dikembangkan dalam pengenalan literasi ini dapat berupa aspek kognitif ataupun bahasa. Target pencapaian perkembangan bahasa anak usia dini yang tercatat dalam STPPA yakni mengenal keaksaraan awal yakni berupa huruf-huruf abjad, selain itu anak dapat mengkomunikasikan atau menceritakan kembali. Sementara itu dalam pengenalan literasi angka yakni anak usia dini ditargetkan dapat membilang minimal 
angka 1-10. Praktek kegiatan pengenalan literasi huruf maupun angka pada anak usia dini kenyataannya masih menjadi satu hal yang dilematis. Di satu sisi banyak penolakan terhadap penerapan baca tulis dan berhitug (CALISTUNG), di sisi lain mendukung adanya penerapan kegiatan itu sebagai upaya untuk mempersiapkan anak usia dini pada jenjang selanjutnya.

Literasi merupakan salah satu dari program pengembangan bahasa pada anak usia dini. Literasi erat kaitannya dengan CALISTUNG. Pengenalan literasi pada anak usia dini, boleh saja dilakukan. Namun pelaksanaannya hendaknya sesuai dengan tingkat pencapaian perkembangan anak dan prinsip pembelajaran pada anak usia dini. Dan memperhatikan cara belajar anak usia dini (Yennizar, 2018). Untuk dapat memenuhi syarat agar pengenalan literasi tidak sampai menyalahi prinsip pembelajaran anak usia dini, guru dituntut untuk kreatif dalam mendesain pembelajaran anak usia dini.

Upaya yang dapat dilakukan untuk meningkatkan kreativitas guru dalam mengenalkan literasi pada anak usia dini salah satunya dengan melakukan pendampingan pembuatan alat permainan edukatif (APE). Kegiatan ini merupakan suatu bentuk pengabdian berbasis riset. Kegiatan pengabdian diarahkan untuk menumbuhkan adanya kesadaran bahwasanya literasi untuk anak usia dini menjadi satu hal yang penting. Perlunya membangun kesadaran guru bahwa mengenalkan literasi untuk anak harus melalui dunia anak yakni dunia bermain. Maka pengenalan permainan literasi dan pendampingan dapat dilakukan pada guru-guru PAUD agar dapat memilih serta mendesain sendiri APE yang akan digunakan sebagai alat bantu dalam melakukan permainan pengenalan literasi untuk anak usia dini. APE ini dapat berupa alat yang membantu guru dalam mengenalkan literasi huruf ataupun literasi angka.

\section{BAHAN DAN METODE}

Dalam kegiatan pengabdian masyarakat berbasis riset ini, kami menggunakan beberapa strategi baik dalam penyampaian materi maupun dalam kegiatan lapangan. Peserta dampingan yang terlibat adalah guru-guru PAUD yang ada di Kecamatan Talun kabupaten Cirebon. Adapun strategi yang digunakan dalam pelaksanaan kegiatan pengabdian ini adalah: Pertama; Teoritik. Penerapan strategi pertama ini ditekankan pada pengenalan pengetahuan dasar tentang literasi. Mengkaji beberapa teori yang berkaitan dengan pentingnya pengenalan literasi untuk anak usia dini. Pelaksanaan strategi yang pertama ini diharapkan dapat menumbuhkan kesadaran guru akan pentingnya metode yang tepat untuk mengenalkan literasi pada anak usia dini. Kegiatan dilakukan dengan Focus Group Discussion, sehingga harapannya dapat mengkolaborasikan pengetahuan awal peserta dampingan dengan teori teori dasar yang disampaikan narasumber. 
Strategi kedua; yakni Praktek langsung. Pada kegiatan ini peserta dampingan diajak untuk mempraktekkan langsung pembuatan media atau alat permainan edukatif untuk pengenalan literasi sesuai dengan materi-materi yang telah disampaikan pada kegiatan teoritik. Guru PAUD diminta untuk membuat APE yang dapat digunakan dalam pengenalan literasi untuk anak usia dini.

Strategi yang ketiga dalam kegiatan pengabdian ini adalah melakukan pendampingan secara kontinyu. Pendampingan dilakukan kepada lembaga PAUD yang terlibat dalam praktek pendampingan pembuatan alat permainan edukatif untuk pengenalan literasi anak usia dini. Dalam kegiatan pendampingan, kami secara langsung mendampingi-guru-guru PAUD bagaimana menggunakan alat permainan yang telah dibuat dalam mengembangkan literasi anak usia dini. Selain mendampingi pemanfaatan APE yang telah dibuat dalam sesi praktek, pendampingan juga dilakukan untuk membuka kemungkinan modifikasi APE baru yang dibuat oleh guru PAUD. Untuk intensitas komunikasi dalam pendampingan digunakan sosial media Whatsapp Group sebagai media berkomunikasi. Dalam group sosial media tersebut peserta dampingan dapat mengkonsultasikan praktek pembelajaran yang dilakukan dengan menggunakan APE atau mengkomunikasikan ide ide modifikasi pembuatan APE yang baru.

\section{HASIL DAN PEMBAHASAN}

\section{Menumbuhkan Kesadaran Guru Pentingnya Pengenalan Literasi Sejak Dini}

Pengabdian berbasis riset ini dilaksanakan untuk menumbuhkan kesadaran guru pentingnya pengenalan literasi sejak dini. Berdasarkan survei yang dilakukan oleh International Education Achievement (IEA) pada awal tahun 2000 menunjukkan bahwa kualitas membaca anak-anak Indonesia menduduki urutan ke 29 dari 31 negara yang diteliti di Asia, Afrika, Eropa dan Amerika. Dengan demikian tidaklah mengherankan bila Indeks kualitas sumber daya manusia Indonesia masih rendah dibandingkan negara-negara tetangga seperti Malaysia atau Thailand serta Singapura. Hilangnya budaya membaca merupakan penyebab yang paling utama (Rohman, 2017).

Literasi erat kaitannya dengan pengembangan bahasa anak usia dini. Belajar bahasa sering dibedakan menjadi dua, yaitu belajar bahasa untuk komunikasi dan belajar literasi, yaitu belajar membaca dan menulis"(Guswarni, n.d.). Kemampuan bahasa yang terakhir inilah menjadi perbincangan hangat dalam pendidikan anak usia dini. Adanya kepentinggan mempersiapkan anak untuk jenjang sekolah dasar, sehingga guru menekankan CALISTUNG. 
Untuk itu pelaksanaan pengenalan literasi sejak dini sangat mungkin dilakukan asalkan sesuai dengan prinsip pembelajaran anak usia dini.

Sebuah gerakan untuk menumbuhkan kesadaran literasi secara nasional telah digagas dengan sebuah nama GLN (Gerakan Literasi Nasional). Gerakan ini merupakan upaya untuk memperkuat sinergi antar unit utama pelaku gerakan literasi dengan menghimpun semua potensi dan memperluas keterlibatan public dalam menumbuhkembangkan literasi di Indonesia. Gerakan ini mencakup Gerakan Literasi Sekolah (GLS), Gerakan Literasi Masyarakat (GLM) dan Gerakan Literasi Keluarga (GLK).

Guru PAUD sebagai pendidik anak usia dini dapat berpartisipasi dalam menumbuhkembangkan atau membudayakan literasi baik di sekolah, masyarakat ataupun keluarga. Untuk dapat ambil bagian maka perlu diketahui terlebih dahulu literasi dasar sebagai kecakapan hidup terdiri dari beberapa kemampuan yakni; (1)literasi baca tulis, (2) literasi numerasi, (3) literasi sains, (4) literasi financial, (5) literasi digital dan (6) literasi budaya dan kewargaan. Literasi baca tulis dan numerasi dalam pendidikan anak usia dini yang masih menjadi pembahasan problematic karena di lapangan banyak guru PAUD yang mengenalkan literasi tersebut tidak sesuai dengan prinsip pembelajaran anak usia dini. Ketidaksesuaian ini salah satu penyebabnya adalah kurangnya kreativitas guru dalam mendesain pembelajaran yang menyenangka. Guru PAUD terburu buru menginginkan hasil yang instan dalam proses pengenalan literasi baik baca tulis ataupun numerasi. Guru terbawa arus tuntutan orang tua yang menghendaki anaknya lulus TK sudah membaca sehingga mengesampingkan proses yang harus disesuaikan dengan perkembangan anak.

Melalui kegiatan pengabdian berbasis riset ini, dikenalkan adanya beberapa permainan yang dapat digunakan untuk pengenalan literasi. Sehingga menggugah guru untuk melakukan kreativitas dalam pengembangan Alat Permainan edukatif yang akan dibuat bersama-sama. Guru dikenalkan beberapa alternative permainan yang dapat digunakan seagai stimulasi pengenalan literasi untuk anak usia dini.

Kegiatan Focus Group Discussion untuk pengenalan literasi sejak dini melalui permainan edukatif pun dimanfaatkan oleh guru PAUD yang menjadi peserta dampingan untuk dapat membagikan pengalaman pengalaman yang pernah mereka lakukan baik dalam hal strategi pembelajaran ataupun alat permainan yang pernah dirancang.

\section{Pendampingan Pembuatan Alat Permainan Edukatif untuk Permainan Literasi}

Kegiatan selanjutnya adalah pembuatan media edukatif. Peserta diarahkan untuk membuat sebuah media edukatif yang dapat meningkatkan kemampuan literasi anak usia dini. 
Kegiatan tersebut didampingi secara langsung oleh penerima hibah dan narasumber. Pendampingan dilakukan dari awal pembuatan hingga produk tersebut jadi dan dapat dipergunakan di lembaga masing-masing. Adapun proses pembuatannya, masing-masing peserta dikelompokan berdasarkan asal sekolah yang berdekatan. Kemudian peserta memilih alat dan bahan untuk dibuat media yang dapat mengembangkan literasi anak usia dini. Adapun media yang dibuat oleh peserta yakni Boneka Tangan (Hand Puppet), Kantong Karakter Ajaib, bowling alphabet, alphabet card dan lain lain. Masing-masing kelompok wajib membuat dua jenis media edukatif. Selanjutnya media yang telah dibuat dipresentasikan dan juga diujicobakan di depan peserta lainnya secara bergiliran.

1. Pembuatan hand puppet sebagai media permainan peran atau mendongeng

Untuk menumbuhkan literasi pada anak usia dini, salah satu permainan yang dapat dilakukan adalah bermain peran dengan menggunakan boneka tangan. Anak usia dini dapat melakukan permainan ini dengan atau tanpa dampingan guru. Mereka dapat bermain peran sesuai dengan tema yang ditentukan oleh guru ataupun tanpa tema sesuai imajinasi anak-anak. Dengan bermain peran ataupun guru mendongeng dengan menggunakan boneka tangan, kemampuan berbahasa anak dapat ditumbuhkan. Bahasa lisan menjadi satu hal yang penting untuk perkembangan anak usia dini. Melalui permainan ini anak usia dini dapat meningkatkan perbendaharaan kata yang dimiliki, mengenal istilah atau kata-kata yang baru. Sehingga menumbuhkan literasi baca tulis anak usia dini. Boneka tangan (Hand Puppet) dapat pula digunakan untuk kegiatan mendongeng. Mendongeng ataupun bercerita dapat member banyak manfaatn terhadap perkembangan literasi anak usia dini. Beberapa manfaat mendongeng diantaranya (Khoiruddin, Taulabi, \& Imron, 2016) :

a. Menambah perbendaharaan kata anak.

b. Membangun kelekatan antara pendidik/orangtua dengan anak usia dini

c. Menstimulasi imajinasi anak

d. Kemampuan bicara anak akan berkembang seiring banyaknya kosakata yang didengar

e. Mendongeng dapat menjadi penyampai pesan moral yang paling tepat tanpa menggurui

f. Mendongeng dapat menggugah minat baca pada anak usia dini 


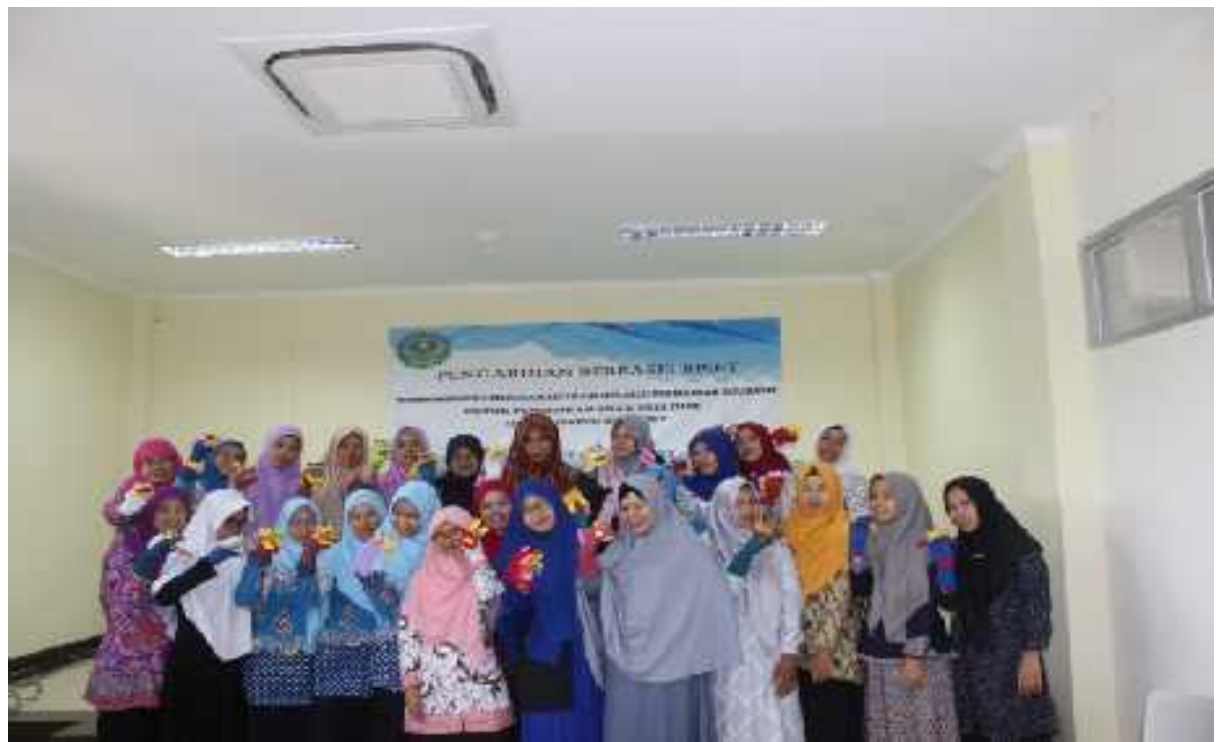

Gambar 1. Peserta membuat hand puppet

\section{Pembuatan Bowling Word}

Permainan edukatif bowling word merupakan satu permainan untuk mengenalkan huruf pada anak usia dini serta menstimulasi perkembangan bahasa utamanya untuk menambah kosa kata anak usia dini. Untuk memainkan permainan bowling word ini dibutuhkan media seperti permainan bowling. Media untuk permainan ini dapat dibuat oleh guru dengan menggunakan bahan bahan bekas. Bahan-bahan yang digunakan yakni botol air mineral bekas, serta kain flannel.

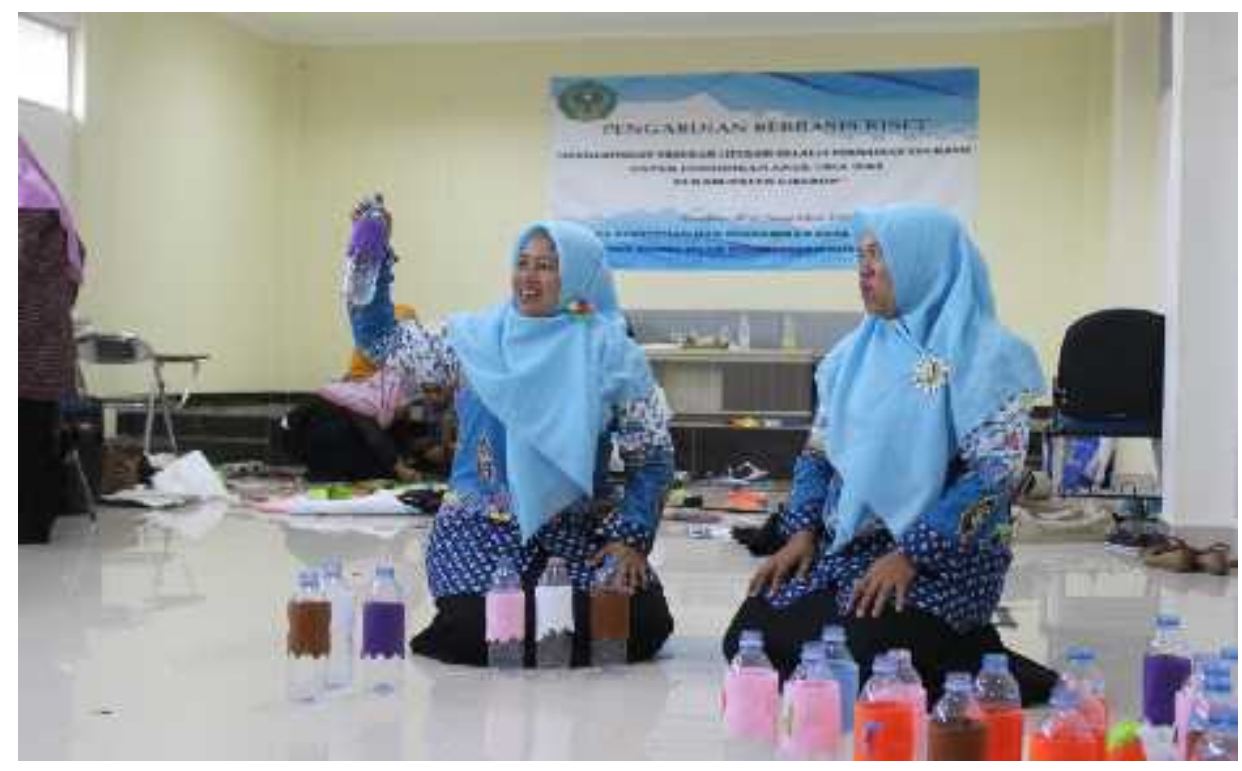

Gambar 2. Bowling Word

Permainan bowling word ini dilakukan oleh anak usia dini dengan dampingan guru. Teknis permainannya sebagai berikut: 
a. Anak menggelindingkan bola bowling yang dibuat dari kertas bekas yang diremas menjadi bulatan dan bungkus kain flannel.

b. Pin bowling yang jatuh diambil oleh anak, lalu guru meminta anak untuk menyebutkan huruf yang tertera di botol bowling.

c. Selanjutnya guru meminta anak menyebutkan beberapa kata dengan huruf dengan seperti pin yang terjatuh tersebut.

d. Untuk teknis pelaksanaan permainan dapat dimodifikasi oleh guru.

Permainan ini dapat digunakan untuk pengenalan huruf atau abjad. Strategi pengenalan huruf sejak usia dini sangat bermanfaat bagi perkembangan bahasa anak, karena membantu mempersiapkan anak untuk dapat membaca dengan mudah. Anak dengan kemampuan pengenalan abjad yang baik dapat memiliki kemampuan yang cepat dalam belajar membaca dan menulis (Pangastuti \& Farida, 2017).

3. Pembuatan Kantong Ajaib Karakter

Kantong Ajaib ini digunakan dalam bermain engklek, media kantong ajaib ini menggunakan kardus bekas yang dibungkus kain flannel yang dibentuk karakter kartun kesukaan anak-anak.

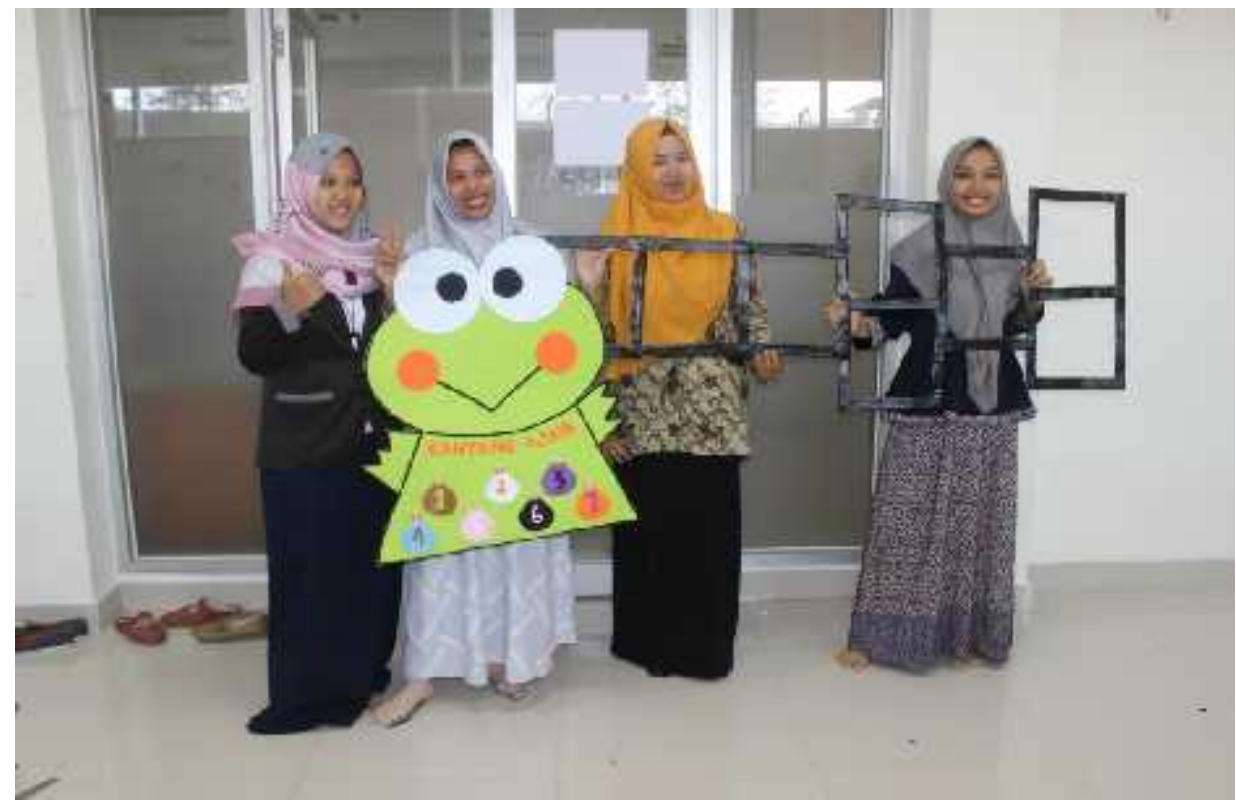

Gambar 3. Kantong Ajaib

Peserta dampingan membuat media permaianan kantong ajaib karakter dan mempraktekkannya saat kegiatan pendampingan in house. 
Permainan ini dilakukan seperti bermain engklek, hanya saja sebelum melakukan engklek anak diminta untuk mengambil kartu yang ada di dalam angka-angka yang ada di kantong ajaib karakter. Kartu tersebut berisi perintah yang harus dilakukan selama melakukan engklek. Dalam permainan ini ketrampilan mendengarkan dan melakukan perintah dilatih pada anak usia dini.

\section{Pembuatan Kartu Huruf}

Bermain kartu huruf menjadi salah satu permainan yang dapat digunakan untuk menumbuhkan literasi pada anak usia dini. Untuk bermain kartu huruf dibutuhkan media kartu huruf yang dapat dibuat menggunakan bahan bahan bekas. Dalam pendampingan yang dilakukan pembuatan kartu huruf menggunakan kardus bekas yang ditutup kertas asturo. Permainan kartu huruf ini dapat dilakukan secara mandiri oleh anak usia dini, ataupun didampingi oleh guru ataupun orangtua.

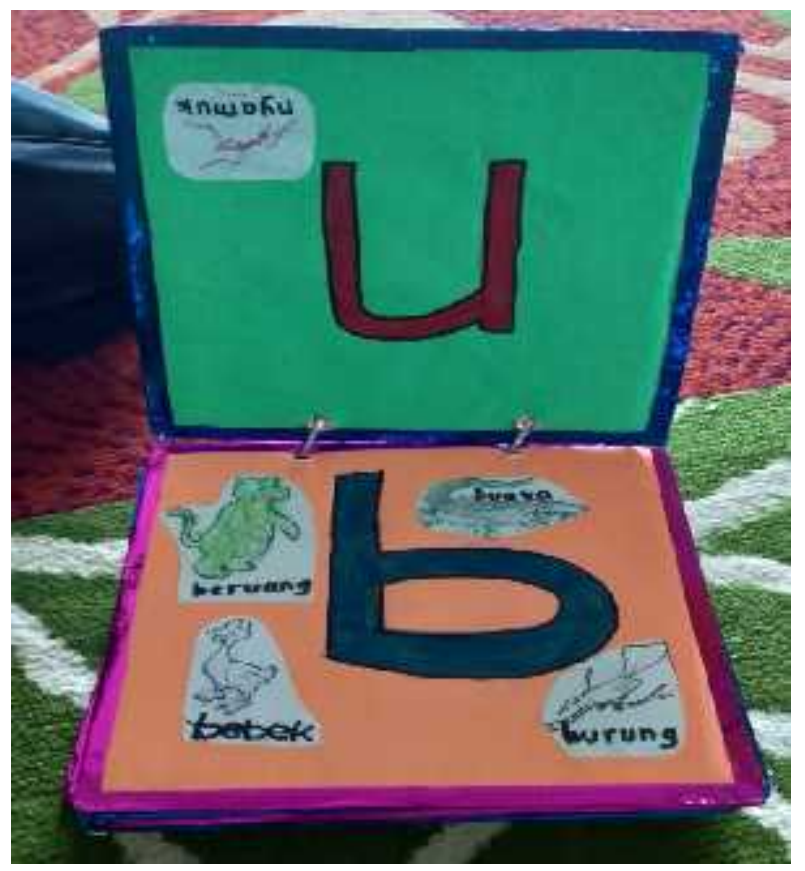

\section{Gambar 4. Kartu huruf produk hasil dampingan yang dibuat peserta}

Mengembangkan media visual Kartu sangat mudah dimainkan oleh anak usia 3-4 tahun. Pengembangan kartu ini diharapkan anak tidak hanya menstimulasi otak kanannya karena bentuknya permainan, tetapi juga merangsang otak kirinya untuk belajar bentuk dan bahkan jadi bisa mengenalnya dan mengeja atau membaca. anak dapat menyebutkan urutan huruf, dapat menghafal huruf (Ratnasari Dwi Ade Chandra, 2017). Pembelajaran yang dilakukan dengan cara menyebutkan simbol huruf abjad yang ada pada media Kartu dapat membantu anak dalam pengenalan baik literasi huruf ataupun angka. 
5. Pembuatan Papan huruf

Permainan edukatif untuk pengenalan literasi selanjutnya yang dibuat selama pendampingan adalah papan huruf. Untuk bermain papan huruf ini dibutuhkan media bermain yang dibuat dari tutup botol bekas dan flannel.

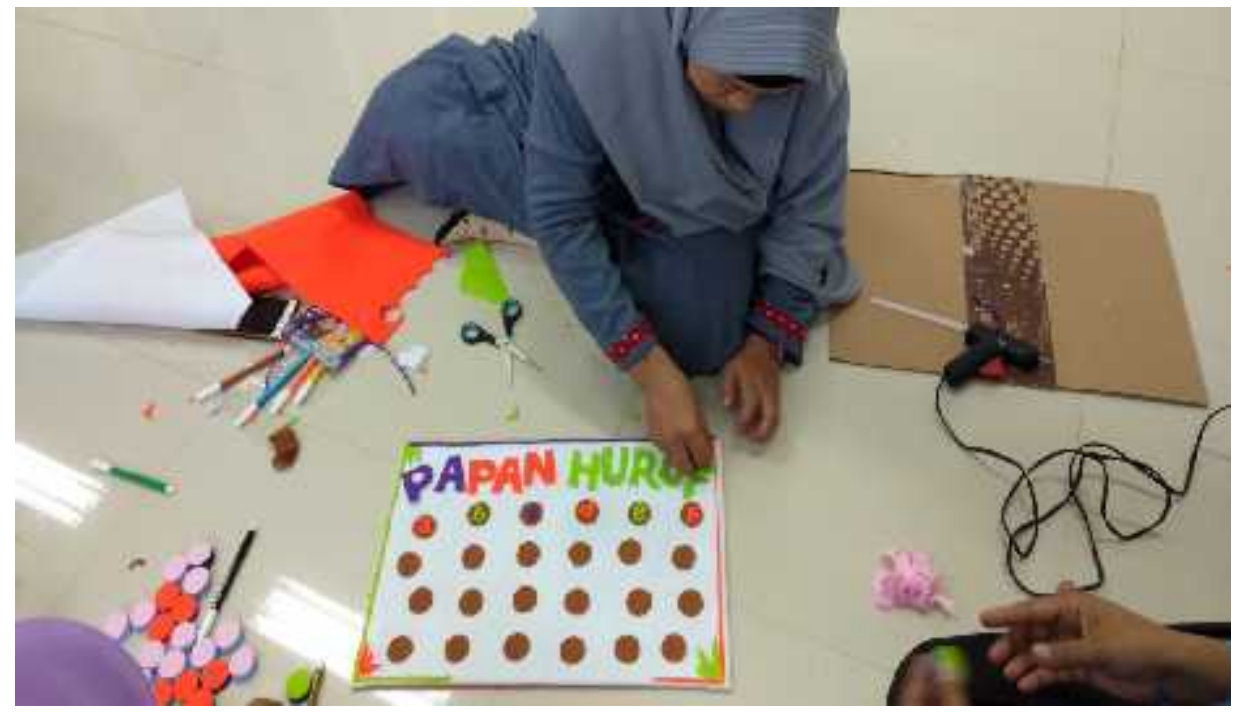

Gambar 5. Peserta dampingan membuat papan huruf

Tutup botol bekas yang dilapisi flannel ditempel huruf-huruf, selanjutnya dapat dimainkan untuk bermain memasangkan huruf yang sama atau susun kata. Permainan memasangkan sangat disukai oleh anak usai dini, permainan ini tepat untuk stimulasi pada anak dalam memahami huruf abjad.

\section{Modifikasi APE yang dihasilkan Peserta Dampingan}

Tahapan yang paling intensif dalam kegiatan pengabdian berbasis riset ini adalah dilakukan pendampingan baik secara online melalui group whatsapp ataupun pendampingan secara offline. Guru yang menjadi peserta dampingan telah dibekali dengan APE yang dibuat saat praktek kegiatan. APE ini diperkenankan untuk dibawa oleh masing masing lembaga yang mengirimkan guru sebagai peserta. Guru yang mengikuti pendampingan melakukan kegiatan untuk mempraktekkan penggunaan APE dalam kelas, serta menjelaskan pada guru lain dalam satu lembaganya tentang cara pembuatan APE untuk pengenalan literasi. Dalam kegiatan ini pengabdi menerima konsultasi via online untuk guru-guru yang memiliki ide modifikasi pada APE yang diikenalkan.

Berdasarkan hasil diskusi dengan subjek dampingan, guru-guru yang mengambil kegiatan ini mampu untuk menumbuhkan kreativitas dalam rangka mengenalkan literasi. Bukti 
bahwasanya kemampuan guru dalam mengembangkan APE mulai berkembang adalah adanya APE yang dihasilkan dari hasil modifikasi APE yang diajarkan dalam kelas praktek. Contoh modifikasi APE yang dibuat oleh seorang guru, adalah berikut ini:

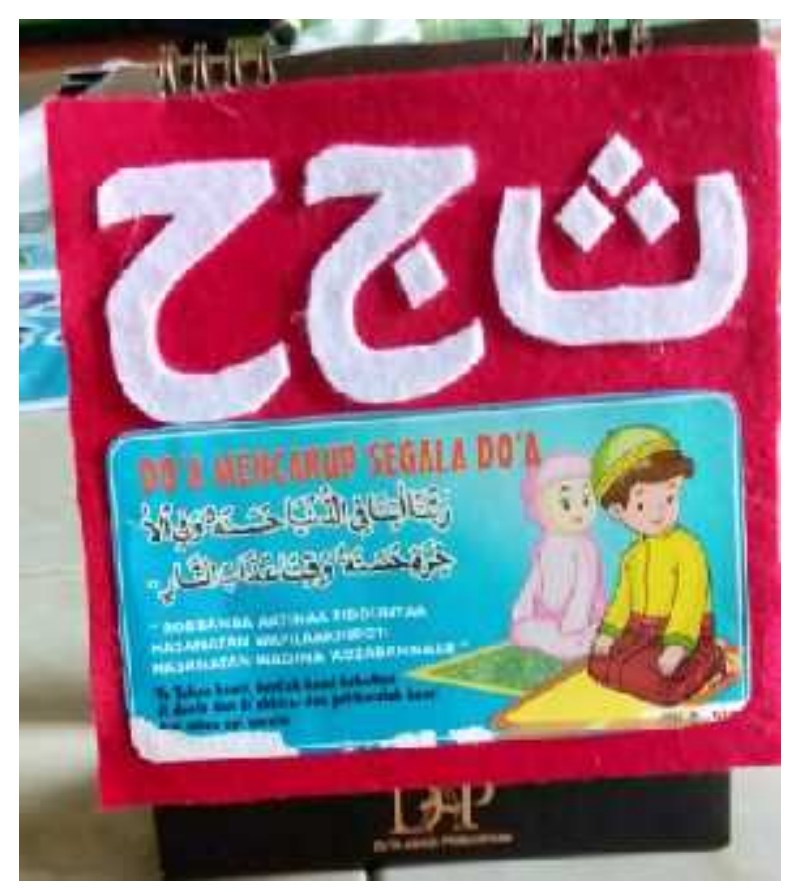

Gambar 6. APE hasil Modifikasi guru PAUD

\section{KESIMPULAN DAN SARAN}

Kegiatan pengabdian berupa pendampingan Pembuatan Alat Permainan Edukatif (APE) Pengelanan Literasi mendapatkan respon yang sangat positif dari para guru subjek dampingan. Penyampaian materi tentang pentingnya literasi untuk anak usia dini telah dipaparkan. Kegiatan praktek pembuatan APE untuk pengenalan literasi telah dilakukan bersama-sama dan dapat diikuti dengan cermat oleh para peserta. Selanjutnya pendampingan pelaksanaan pembelajaran menggunakan APE yang dibuat dilakukan oleh masing masing sekolah. Hasil dampingan yang lain yakni adanya pengembangan atau modifikasi untuk APE yang telah dikenalkan disesuaikan dengan kebutuhan di lembaga, contohnya muncul APE Kalender Hijaiyah untuk pengenalan huruf hijaiyah pada anak usia dini.

\section{UCAPAN TERIMA KASIH}

Penulis mengucapkan terima Kasih kepada semua pihak yang membantu kegiatan pengabdian ini. Secara khusus penulis mengucapkan terima kasih kepada ketua IGRA Kecamatan Talun Kabupaten Cirebon, yang telah memberikan kesempatan kepada penulis untuk melakukan 
pengabdian berbasis riset. Ucapakan terima kasih juga penulis sampaikan kepada IAIN Syekh Nurjati Cirebon yang telah memberikan dukungan berupa dana dan fasilitas dalam kegiatan pengabdian ini. Kegiatan ini dibiayai oleh DIPA IAIN Syekh Nurjati Cirebon 2018.

\section{DAFTAR PUSTAKA}

Arikunto, S. (2013). Prosedur Penelitian Suatu Pendekatan Praktik. Jakarta: Rineka Cipta

Guswarni, E. (n.d.). Peningkatan Kemampuan Membaca Awal Anak Melalui Permainan Kartu Gambar di Taman Kanak Kanak Negeri Pembina Agam. Jurnal Pesona PAUD, 1(1), 1-12.

Khoiruddin, M. A., Taulabi, I., \& Imron, A. (2016). Menumbuhkan Minat Baca Sejak Dini di Taman Baca Masyarakat. Journal An Nafs, 1(2), 291-319.

Pangastuti, R., \& Farida, S. (2017). Pengenalan Abjad pada Anak Usia Dini Melalui Media Kartu Huruf. Al Hikmah: Indonesia Journal of Early CHhildhood Islamic Education, 1(1), 51-66. Permendikbud 137 Tahun 2014 Tentang Standar Nasional PAUD

Pradana, P. H. (2016). Pengaruh Permainan Balok Angka Terhadap Keammpuan Mengenal Lambang Bilangan Pada Anak Usia Dini. Jurnal PAUD Tambusai, Research \& Learning in Early Childhood Education, 2(2), 18-25.

Ratnasari Dwi Ade Chandra. (2017). Pengembangan Media Visual Kartu Angka Efektif untuk Mengenalkan Huruf Vokal A,I,U,E,O Pada Anak Usia Dini 3-4 Tahun PAUD Labschool Jember. INDRIA, Jurnal Ilmiah Pendidikan PraSekolah Dan Sekolah Awal, II(1), 45-71.

Rohman, S. (2017). Membangun Budaya Membaca Pada Anak Melalui Program Gerakan Literasi Sekolah. TERAMPIL Jurnal Pendidikan Dan Pembelajaran Dasar, 4(1), 151-174.

Yennizar. (2018). Optimalisasi Pengenalan Literasi Pada Anak Usia Dini Melalui Pendekatan Saintifik. JISEC (Journal of Islamic Studies For Early Childhood, 1(1). 